\section{E-LOGOS}

ELECTRONIC JOURNAL FOR PHILOSOPHY ISSN 1211-0442

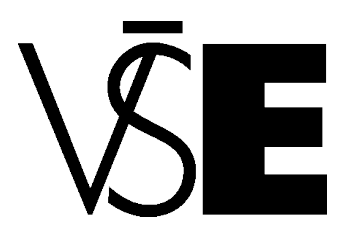

University of Economics

Prague

\title{
Kritické zamyšlení nad metodou zkoumání rakouské školy
}

Zdeněk Pikhart

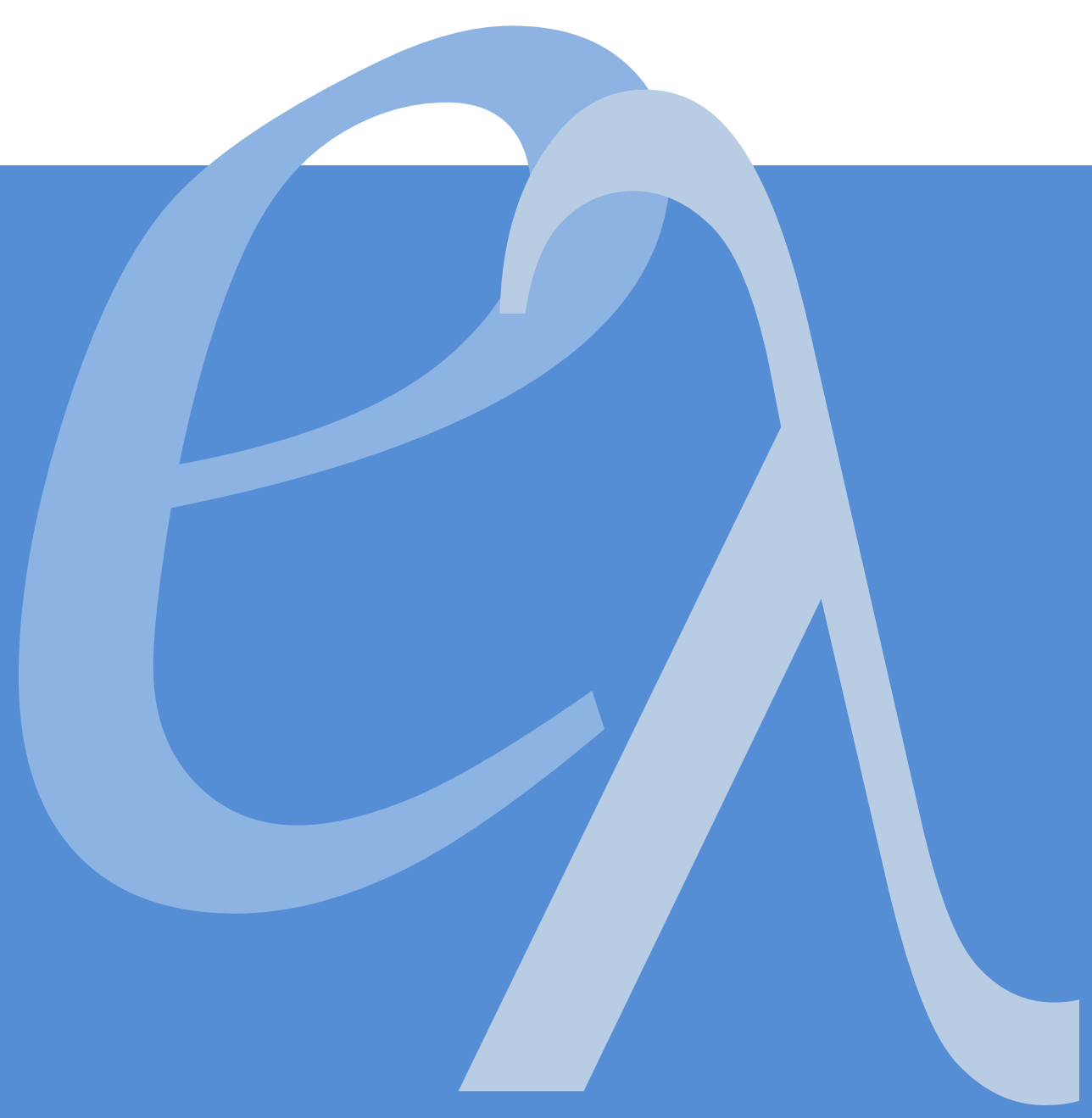




\begin{abstract}
The article deals with a critical analysis of the main methods of examining the Austrian school of economics. First, attention is paid to methodological individualism and subjectivism and potential problems that are associated with their fully consistent application. It is explained illegitimacy critique of mainstream economics by Austrian school in terms of praxeological law. The last chapter is devoted to criticism of the axiomatic understanding of rationality as a necessary precondition for methodological individualism and praxeology.
\end{abstract}

Keywords: Austrian school, methodological individualism, praxeology, rationality

\begin{abstract}
Abstrakt
Článek se zabývá kritickým rozborem hlavních metod zkoumání rakouské ekonomické školy. Nejprve je pozornost věnována metodologickému individualismu a subjektivismu a možných problémů, které jsou spojeny s jejich plně konzistentním uplatňováním. Dále je vysvětlena neoprávněnost kritiky ekonomie hlavního proudu rakouskou školou z hlediska praxeologického zákona. Poslední kapitola se věnuje kritice axiomatického chápání racionality jakožto nutného předpokladu pro metodologický individualismus a praxeologii.
\end{abstract}

Klíčová slova: rakouská škola, metodologický individualismus, praxeologie, racionalita 


\section{Úvod}

Rakouská ekonomická škola představuje alternativní proud ekonomického učení, který se od současného hlavního proudu ekonomie v mnoha oblastech liší a jde si svou vlastní cestou. Rakouská ekonomie se vyvíjela od 19. století jako protipól německé historické ekonomické školy. Mezi nejvýznamnější rakouské ekonomy té doby patřil Carl Menger a Eugen Böhm-Bawerk, kteři vystavěli rakouskou ekonomii na metodologii opírající se o důslednou aplikaci metodologického individualismu a subjektivismu. Právě metoda zkoumání a odklon od empiricko-historické metody představoval největši rozdíl oproti německé ekonomické škole. Rakušané argumentovali nemožností popisu lidského jednání na základě historických pozorování. Své argumenty opírali právě o metodologický individualismus a subjektivismus. Rakouská ekonomie té doby se př́liš nelišila od neoklasické ekonomické školy.

Pozděǰši generace rakouských ekonomů, která zásadně rozpracovala Mengerovo a Böhm-Bawerkovo ekonomické učení, zaměřila svou pozornost na detailní kritiku státních zásahů a zásadně se tak vymezila proti ekonomii hlavního proudu. Hlavními představiteli byli Ludwig von Mises, Murray N. Rothbard a Friedrich August von Hayek.

V následujících kapitolách vysvětlíme a kriticky rozebereme tři hlavní metodické pilî̌re rakouské školy - metodologický individualismus a subjektivismus, praxeologický zákon a předpoklad racionality. Cílem je zasadit ortodoxní rakouská paradigmata a axiomy do kontextu ekonomické reality. Pokusíme se vyzdvihnout silné a slabé stránky metody zkoumání rakouské školy a možná rizika, které z její aplikace vyplývají.

\section{Metodologický individualismus a subjektivismus}

Metodologický individualismus vysvětluje ekonomické jevy výhradně z chování jednotlivců. Metodologický subjektivismus dále zdůrazňuje, že lidské konání vychází ze subjektivních potřeb, užitku, znalostí, vnímání, očekávání atd. (Kirzner 1992)

Rakouská škola není jediná, která staví na metodologickém individualismu. Také standardní neoklasická ekonomie vychází v makroekonomii z mikroekonomických základů, nicméně dopouští se agregací, což rakušané důsledné odmítají. Užitková funkce je $\mathrm{v}$ pohledu mainstreamu také individuální veličinou vycházející ze subjektivního vnímání konkrétního jedince. Avšak zde podobnosti končí.

Nezasvěcený pozorovatel by nejspíše nabyl dojmu, že mainstreamová ekonomie a rakouská ekonomická škola $\mathrm{v}$ důsledku podobné metodě a dílčích rozporů v její aplikaci nabydou podobných závěrů a výstupů ekonomického bádání. Opak je pravdou. 
Především radikálnější křídlo rakouských ekonomů, které vychází zejména z Rothbarda, aplikují výše zmíněné metody následovně. Jestliže nelze užitek změřit, sčítat, porovnávat a základem ekonomického rozhodování je jedinec, tak jakékoli pokusy o makroekonomické generalizace jsou liché. Dle rakušanů tak nic jako národní hospodářství ve skutečnosti existovat nemůže, protože jde o naprosto smyšlenou a umělou entitu. Jediný kdo hraje v ekonomickém zkoumání roli, je jednotlivec.

Z důsledného lpění na výše uvedené metodě tedy vyplývají zásadní teoretické implikace pro rakouskou ekonomii. Matematizace ekonomie je kontraproduktivní, protože žádný sebesložitější matematický vzorec nemůže popsat lidské chování v jeho komplexnosti. Jedinou možnou metodou výkladu je tak verbální hodnotově neutrální popis ekonomických jevů.

Statistická verifikace, teorie pravděpodobnosti, či ekonometrie nejsou z hlediska vědeckosti zkoumání a metodologické konzistence dostatečně relevantní pro ekonomický výzkum. Jakýkoli výsledek pouze vypovídá o minulých datech, ale neříká nic o budoucím vývoji, protože preference každého jedince se mohou neustále měnit na základě jeho postojů, poučení se $\mathrm{z}$ chyb, interakce s okolím a tisíců dalších proměnných - náhodných i záměrných.

Počítání výstupu národního hospodářství a kvantifikace ekonomických vztahů v rámci něho i vně pomocí nástroje národního účetnictví, platební bilance a ostatních statistik není v souladu s metodologií rakouské ekonomické školy.

Rakušané jdou však se svou metodologickou konzistencí ještě dál. Rothbard (2005) ve svém díle kritizuje činnost státu jako zločinné organizace, jejíž činnost odporuje platnosti metodologického individualismu a metodologického subjektivismu. $\mathrm{V}$ př́ípadě, že si lidé budou stát přát, nebude logicky třeba donucovacích prostředků k financování jeho činnosti. Jestliže se část lidí cítí být existencí státu poškozena, ztráta jejich užitku může být vyšší než zisk užitku zbytku společnosti. Rothbard argumentuje dokonce ad absurdum. Pokud všichni ve společnosti budou mít ze státu užitek a bude existovat byt' jediný člověk, který se bude cítit jeho existencí poškozen, jeho ztráta může být nezměrná a převýšit přínos všech ostatních. Stále to nepředstavuje nejmenší argument pro povinné vybírání daní.

V souhrnu tak naprosto konzistentně a důsledně uplatňovaná metoda zkoumání založená na metodologickém individualismu vylučuje jakékoli agregace ekonomické aktivity, použití statistik pro ekonomický výzkum a existenci státu a cokoli spojeného se zákonným donucením.

Rakušané však nenavrhují absenci jakýchkoli práv, nýbrž zdůrazňují respektování tzv. přirozených lidských práv, tedy právo na vlastnictví sama sebe a v důsledku toho na plody své vlastní práce. Na jaké úrovni, pro koho by daná práva byla deklarována a kým vynucována, už rakouští ekonomové považují za detailní technikálii, kterou 
není nutné obecné teoretizování komplikovat. Lidé jsou dle nich nesmírně inovativní a v zásadě tak ze svobodné soutěže na trhu vzejde mix právních agentur, které zajistí vymahatelnost práva efektivněji než stát.

Tot' sumarizace konsekvencí plynoucích z doslovného uplatňování metodologického individualismu rakouskou ekonomickou školou. Nyní se podíváme na možné praktické nedostatky výše uvedeného metodologického př́istupu.

Představme si, že ekonomové chtějí zanalyzovat např́iklad spotřební chování domácností při konzumaci tabákových výrobků. Na základě dostupné cenové statistiky a reálné produkce tak mohou na dostatečně dlouhé časové řadě odhadnout cenovou elasticitu poptávky po cigaretách. $Z$ hlediska jednotlivé firmy není tento agregátní údaj př́liš důležitý, protože tu zajímá především poptávka po její produkci a elasticita poptávky po jejích výrobcích. Nicméně např. pro zákonodárce, který řeší optimální výši spotřební daně na cigarety z hlediska dopadu na výnos daně, daňové úniky, distorze či internalizaci nákladněǰ̌i léčby pacienta kuřáka, je výše zmíněný údaj klíčový.

Bez použití dostupných statistik a statisticko-ekonometrických metod bychom stěží tento údaj zjistili. Rakouský ekonom jistě namítne, že zjištěný údaj nemá žádnou relevanci s ohledem na budoucí vývoj. Mainstramový ekonom bude oponovat, že jde o obecnou vlastnost statistiky, avšak to nevylučuje přijetí rozumného předpokladu o nevýznamné změně chování v blízké budoucnosti. Je velmi málo pravděpodobné, že kuřáci, kteří např. dvacet let demonstrovali své preference na trhu nějakým způsobem, budou v př́štích několika letech radiálně měnit své spotřební chování.

Zde narážíme na klíčový metodologický rozpor. Ekonom statistik vyšel z metodologického realismu, kdy vzal $\mathrm{v}$ potaz reálné předpoklady vývoje kuřákova chování. Usoudil, že jejich chování je značně setrvačné a rigidní a učinil předpoklad, že neelastická poptávka bude s nejvyšší pravděpodobností přetrvávat i v nejbližších letech. Díky tomu mohl výsledky svého výzkumu interpretovat s ohledem na budoucnost a přispět tak do řešení celospolečenského problému.

Naproti tomu rakouský ekonom nepoužil statistiku, ani ekonometrii z toho důvodu, že uvažoval vysokou nestálost chování do budoucna. To předpokládal nikoli na základě empirického sledování a zkoumání reality, nýbrž na základě teoretických východisek metodologického individualismu. Empirie dle rakouského ekonoma tak neříká naprosto nic o budoucnosti a je tedy z hlediska ekonomické teorie nevědecká. Rakouský ekonom tak výše uvedený problém reálné neřešil, protože neudělal vůbec nic pro to, aby se situace zlepšila.

Dalším př́kladem, kterým uvedeme, je použití statistik národního účetnictví a platební bilance. Údaje o ekonomických tocích s nerezidenty a produkci ekonomiky poskytují neuvěřitelně významný nástroj pro ekonomické zkoumání, hospodářsko- 
politickou praxi a rozhodování ekonomických subjektů. Právě díky těmto statistikám mohou ekonomové rozklíčovat přičiny a důsledky mnohých krizí, ale i úspěchů a na základě výzkumu učinit doporučení. Můžeme tak porovnávat ekonomickou vyspělost různých zemí, hodnotit fungování měnových režimů a celé řady vládních politik a národních specifik. Takovýto statistický nástroj dává ekonomům do ruky silný argument proti mnoha škodlivým vládním politikám, na které by se jinak prrišlo pouze s velkým zpožděním a logicky i vysokými náklady. Oproti tomu mohou dnešní politici mnohem flexibilněji reagovat na měnící se podmínky a sledovat úspěšné př́klady z jiných zemí, protože statistika činí voliče informovanými. Nic takového ještě před sto lety nešlo a celé země tak směřovaly mnohdy do slepých uliček za nevědomosti svých obyvatel.

Aby vůbec mohly být tyto národní, sektorové i regionální bilance sestrojeny, museli tvůrci vytvořit jednotnou metodiku za mnoha ad hoc předpokladů vycházejících z metodologického realismu. Výsledek však dává velmi přesnou aproximaci produkce a mnoha dalších toků a pro výše zmíněné účely je více než postačující.

Posledním a zréejmě i nejkřiklavějším příkladem aplikace metodologického individualismu je odmítání všeho státního nezanedbatelnou částí rakouských ekonomů. Rakušané (Rothbardovské křídlo) popírají existenci tržních selhání, protože tvrdí, že trh vše vyřeší sám pouze ve své nejčistší, neregulované formě. Jinými slovy nelze lidem zasahovat do životů, protože neznáme užitkovou funkci jednoho každého z nich a nutně každým zásahem musíme někoho omezit, či poškodit, což je z hlediska metodologického individualismu nezpochybnitelné.

Přemýšlivý člověk se samozřejmě pouze s takovýmto argumentem nespokojí. Na řadě je tedy řada otázek $\mathrm{z}$ reálného světa. Kdo zabezpečí právo a kdo ho bude vymáhat? Bude tržní vymáhání spravedlivé a efektivní? Jaké právo to bude a kde je garance, že půjde zrovna o právo přirozené? Kdo zajistí fungování armády tak, aby efektivně plnila svou funkci $\mathrm{s}$ úsporami $\mathrm{z}$ rozsahu a současně nezneužila svého postavení k podmanění neozbrojených civilistů, kterým měla původně sloužit? Kdo zajistí internalizaci externalit, které nejdou vyřešit vymezením vlastnických práv, např. znečištění ovzduší a vod, hluk, prašnost atd.? Kdo sníží informační neefektivnost na některých trzích, která brání dalšímu hospodářskému růstu? Toto je pouze vzorek rakouskou školou dostatečně nezodpovězených otázek. Dokud se rakouští ekonomové neoprostí své metodologické svěrací kazajky, nebudou na ně schopni nalézt jiný než jeden univerzální teoreticko-metodologický argument.

Bezmezné lpění na metodě zkoumání může velice snadno způsobit zamítnutí mnoha jiných užitečných metod, které by se $\mathrm{k}$ vysvětlení a řešení dané problematiky hodily lépe. Nepochopení faktu, kdy se každý individuální jedinec může chovat racionálně, a přesto dojde $\mathrm{k}$ něčemu, co nikdo $\mathrm{z}$ nás nechce, je má fundamentální kritika rakouské ekonomické školy. Zvýší-li ekonomické subjekty z různých důvodů 
skokově úspory, onen převis úspor nad investicemi nebude moci být proinvestován a ekonomika se vyrovná poklesem agregátní poptávky a růstem nezaměstnanosti. Pouze za poklesu mezd, který nebude dále tlačit na růst spotřebního pesimismu domácností, může ekonomika skrze pokles cen zvýšit reálnou produkci a odstranit nedobrovolnou nezaměstnanost. Nicméně empirická data ukazují, že tento proces probíhá díky rakušany opomíjeným nominálním a reálným rigiditám velmi pomalu a bolestně. Včasný pokles úrokové míry centrální banky reagující na růst míry úspor a deflační tlaky umožňuje mnohem hladší průběh hospodářského cyklu. Rakouská ekonomie sice popisuje mechanismy vyrovnávání skrze postupnou reakci úrokových měr a pokles cen, avšak to nic nemění na tom, že jsou dostupná jiná řešení, která mohou být efektivnější z hlediska dopadu do produkce a nezaměstnanosti. Je poté fundamentálním neporozuměním lidskému jednání, které nejen rakušané zkoumají, bojovat proti ustanovení takového institucionálního uspořádaní, které onu lepší variantu umožňuje realizovat. Je navýsost patrné, že chceme-li se jako ekonomové takovými tématy, trápící společnost vážně zabývat, nesmíme chápat ekonomii jako ryze pozitivní, deskriptivní vědu, ale taktéž jako vědu o institucionálním uspořádání, nastavení systému a hospodářských doporučeních, tedy vědu normativní.

\section{Praxeologie}

Praxeologický zákon je dalším metodologickým východiskem rakouské ekonomické školy. Jeho podstatou je tvrzení, že člověk svobodně jedná na trhu tak, aby maximalizoval svůj užitek, demonstruje své preference. Žádná lepší varianta nemůže být dostupná, protože nikdo nezná užitkovou funkci lépe než samotný aktér, který nese náklady i užitky svého počínání. Předpokladem je racionalita spotřebitele, které se budeme věnovat v následující kapitole.

Rakouská ekonomie kritizuje kardinalistické i ordinalistické pojetí užitku v moderní mikroekonomii. Užitek je dle nich neměřitelný a ani vzájemným porovnáváním statků a služeb mezi sebou nemůžeme a priori zjistit tzv. indiferenční křivku. Ta je dle rakušanů (Rothbard 2005) pouze imaginárním konstruktem, protože lidé vždy nějak své preference demonstrují, nemohou být tedy indiferentní.

Kritika indiferenční analýzy optikou praxeologie je však značně zavádějící, protože používá několik demagogických, či neznalostních argumentačních faulů. Indiferenční křivka je abstrakce, která má sloužit k lepšímu vysvětlení chování spotřebitele. $\mathrm{V}$ žádné učebnici ekonomie se nedočteme, že je neměnná. Navíc zjistíme, že indiferenční analýza není úplná bez znalosti linie rozpočtu. Po zapracování obou křivek a racionální volby nejvyšší indiferenční křivky, která se dotýká linie rozpočtu, dostaneme spotřebitelovo optimum, tedy jeho preference, které je připraven demonstrovat na trhu v daný moment. Tento mix statků bude na trhu reálně poptávat. Proto je mylné tvrdit, že je spotřebitel mezi variantami indiferentní. Klidně se může 
stát, že se nejvyšší indiferenční křivka protne s linií rozpočtu přesně v bodě průsečíku $\mathrm{s}$ jednou, či druhou osou, z čehož vyplývá, že spotřebitel bude volit pouze jeden výrobek $\mathrm{v}$ důsledku jeho vyšší preference plynoucí z vyššího užitku při respektování rozpočtového omezení.

Ačkoli se tedy může zdát koncept demonstrovaných preferencí jako tautologie, není tomu tak, jde pouze o teoretickou abstrakci spotřebitelského chování za předpokladu racionality. $\mathrm{V}$ zásadě se tak rakouská praxeologická metoda neliší od indiferenční analýzy mainstreamové ekonomie, nicméně sami rakouští ekonomové si toho patrně nejsou vědomi.

Ekonomové se dále zabývají efektivností výběru, protože nás zajímá, jestli není spotřebitelské chování zatíženo některým typem tržního selhání, především informační asymetrií. Mnohdy tak lze docílit obecně efektivnějších tržních řešení a zvýšení uspokojení potřeb formou některého typu informační povinnosti. Tato informace navíc výrobce prakticky nic nestojí a spotřebitel se díky ní může mnohem lépe orientovat na trhu a vybírat $\mathrm{z}$ dostupných variant. Jde zejména o povinnost uvést složení potravin na obalu, náležitosti finančních a jiných smluv atd. Můžeme sem zařadit také hygienické kontroly restaurací, protože zákazník si není schopen ověřit nezávadnost skladování a př́pravy pokrmů. $\mathrm{V}$ těchto reálných příkladech však rakouská ekonomická škola zachovává striktní averzi vůči jakýmkoli státním zásahům především z metodologických důvodů.

\section{Racionalita}

Předpokladem pro metodologický individualismus a praxeologii je racionalita ekonomického subjektu. Rakouská ekonomie chápe racionalitu axiomaticky jako takové jednání, při němž člověk maximalizuje svůj očekávaný užitek. (Mises 2006) Slovo očekávaný je $\mathrm{v}$ definici velmi důležité. Často se $\mathrm{v}$ ekonomických médiích vyskytují tvrzení, která popírají racionalitu spotřebitele, či investora $\mathrm{z}$ toho důvodu, že jednal ex post špatně. To však je pouze neporozumění původní Misesově definici, protože ta nic neříká o tom, že lidské jednání musí být zpětně hodnoceno dobře, či špatně. Spotřebitel se pohybuje v prostoru a čase s omezenými informacemi a na základě nich činí rozhodnutí. $\mathrm{V}$ prŕpadě špatného rozhodnutí informaci vyhodnotí $\mathrm{a}$ upraví svá budoucí očekávání.

Informace nejsou zadarmo, jejich získání vyžaduje úsilí a čas, nezř́dka kdy peníze, proto se spotřebitel vyznačuje tzv. racionální neznalostí, kdy vynaloží vzácné zdroje pouze na získání takových informací, o kterých se domnívá, že mu s vysokou pravděpodobností pomohou učinit lepší rozhodnutí a zvýšení užitku převýší náklady na opatření informace.

Ekonomie hlavního proudu je s definicí racionality jedince na základě maximalizace očekávaného zisku při platnosti tranzitivity preferencí (Salvatore 2008) ve shodě 
s rakouskou školou. Avšak s příchodem teorie racionálních očekávání, efektivních trhů a behaviorálních financí začal s definicí racionality v ekonomii zmatek. Psychologové zaměňují výše uvedenou definici racionality s nepromítnutím emocí do rozhodování. Např. Simon (1990) dokládá omezenou racionalitu jedince na neschopnosti uvážit všechny stránky rozhodnutí, před nímž stojí, případně nevyhledání všech relevantních informací a jejich neověřením atd. Proto dnes ekonomie hlavního proudu důsledně rozlišuje mezi racionalitou, racionálními očekáváními, př́padně efektivitou a nemíchá definici racionality v ekonomii s definicí racionality v psychologii, z které vycházejí behaviorální ekonomové.

Rakouská definice racionality je tak po logicko-teoretické stránce velmi robustní. Jistou kontroverzi však shledávám v jejím axiomatickém chápání. Rakušané považují všechny lidi bez rozdílu za racionální, což je dle mne nerealistický předpoklad. Většina lidí zpravidla racionální je, ale jsou ve společnosti skupiny lidí, které vykazují známky omezené racionality. Právě na takovéto lidi se zpravidla vztahuje zákonná ochrana, či nějaký druh sociální pomoci. Jako př́ílad můžeme uvést duševně nemocné, malé děti, silně drogové závislé a lidi na pokraji nervového zhroucení či vyhoření.

Pokud bychom $\mathrm{v}$ zákonech požadovali stejná práva a povinnosti pro duševně nemocné a malé děti jako pro zdravé a dospělé jedince, vytvořili bychom podmínky pro bezmezné zneužívání lidské bezbrannosti. Nebyl by problém sepsat nevýhodnou smlouvu na cokoli a podstrčit ji onomu člověku a mnoho dalších věcí. Ve světě podle rakušanů by si mohl rodič se svým dítětem dělat prakticky, co chce. Sociální záchranná sít umožňuje s nízkými náklady na vyhledávání potřebných efektivně zasáhnout a pomoci člověku při návratu zpět do normálního života při znalosti rizik s jejím fungováním spojených. Takto institucionalizovaná pomoc snižuje kriminalitu, sociální pnutí, zvyšuje solidaritu s potřebnými a v neposlední řadě urychluje začlenění do ekonomického procesu. Činnost soukromých decentralizovaných charit může fungovat pouze jako doplněk, nikoli jako skutečná náhrada.

\section{Závěr}

Teorie rakouské ekonomické školy patří mezi silně metodologicky ukotvené. Její metoda zkoumání je založena na čistě logicko-deduktivních metodách. Škola se opírá zejména o metodologický individualismus a subjektivismus, praxeologii za předpokladu axiomatického chápání racionality.

Metody zkoumání rakouské školy nepřipouštějí jiné alternativy a mnohdy tak uměle uzavřou cestu $\mathrm{k}$ jiným a př́nosnějším způsobům ekonomického výzkumu, což je možná z čistě teoretického hlediska nenapadnutelné, avšak z hlediska hospodářskopolitické praxe a pohledu ekonomie jakožto vědy dívající se na lidské jednání komplexně v kontextu vzácnosti zdrojů a jejich užití kontraproduktivní. 


\section{Bibliografie}

Böhm-Bawerk, Eugen. Capital and Interest. 1. vydání, London, Macmillan and co., 1890.

Hayek, August von. Individualism and Economic Order. 1. vydání, London, University of Chicago Press Ltd., 1948.

Kirzner, Israel. The Meaning of Market Process, Essays in the development of modern Austrian economcs. 1. vydání, Londýn a New York, Routledge, 1992.

Menger, Carl. Principles of Economics. 2. vydání, New York, New York University Press, 1981.

Mises, Ludwig. Lidské jednání - pojednání o ekonomii. 2. vydání, Praha, Liberální institut, 2006.

Rothbard, N. Murray. Ekonomie státních zásahů. 1. vydání, Praha, Liberální institut, 2005.

Salvatore, Dominick. Microeconomics: Theory and Applications. 4. vydání, New York, Oxford University Press, 2008.

Simon, A. Herbert. A mechanism for social selection and succesfull altruism. Science 250, 1990. 


\section{E-LOGOS}

ELECTRONIC JOURNAL FOR PHILOSOPHY

Ročník/Year: 2013 (vychází průběžně/ published continuously)

Místo vydání/Place of edition: Praha

ISSN 1211-0442

Vydává/Publisher:

Vysoká škola ekonomická v Praze / University of Economics, Prague

nám. W. Churchilla 4

Czech Republic

13067 Praha 3

IČ: 61384399

Web: http://e-logos.vse.cz

Redakce a technické informace/Editorial staff and technical information:

Miroslav Vacura

vacuram@vse.cz

Redakční rada/Board of editors:

Ladislav Benyovszky (FHS UK Praha, Czech Republic)

Ivan Blecha (FF UP Olomouc, Czech Republic)

Martin Hemelík (VŠP Jihlava, Czech Republic)

Angelo Marocco (Pontifical Athenaeum Regina Apostolorum, Rome, Italy)

Jozef Kelemen (FPF SU Opava, Czech Republic)

Daniel Kroupa (ZU Plzeň, Czech Republic)

Vladimír Kvasnička (FIIT STU Bratislava, Slovak Republic)

Jaroslav Novotný (FHS UK Praha, Czech Republic)

Jakub Novotný (VŠP Jihlava, Czech Republic)

Ján Pavlík (editor-in-chief) (VŠE Praha, Czech Republic)

Karel Pstružina (VŠE Praha, Czech Republic)

Miroslav Vacura (executive editor) (VŠE Praha, Czech Republic) 